\title{
Identification of strategies for enhancing member commitment in Greek agricultural cooperatives: The opinion of cooperative experts
}

\author{
Identificación de estrategias para mejorar el compromiso de los miembros en \\ las cooperativas agrícolas griegas: la opinión de los expertos en cooperativas \\ DOI: $10.22458 /$ rna.v12i2.3777 \\ CIRIEC-UNED 2021-030-035
}

Tilemachos Manousakis

MSc candidate of Business Economics and Management

Mediteranean Agronomic Institute of Chania, Chania, Greece,

tilem.manousakis@gmail.com,https://orcid.org/0000-0002-0577-0034

\author{
Panagiota Sergaki \\ Associate Professor of Agricultural Cooperation at Aristotle \\ University of Thessaloniki, Thessaloniki, Greece, \\ gsergaki@auth.gr, https://orcid.org/0000-0003-1717-7091
}

\author{
Gert Van Dijk \\ Professor of Cooperative Business Administration and Management \\ Nyenrode Business University, Amsterdam, The Netherlands, \\ g.vdijk@,nyenrode.nl,https://orcid.org/0000-0001-8916-6231
}

\begin{abstract}
:
In the era of globalization, where competition is growing intensively, the cooperation between small scale farmers can assist them to be sustainable and survive. However, the situation with cooperatives in Greece is found to be on a downward trend due to their poor economic performance, which is later expressed by the diminished commitment of their members. In order to address the described problem we employed a qualitative study consisted of 10 guided interviewees with "cooperative experts". Through the interviews the participants were asked to clarify their opinions on two major themes: 1) Common Greek cooperative issues, and 2) Suggestions on strategies employed by cooperatives to enhance members' commitment. Through our analysis we identified the issues related to the poor management of the cooperatives of the past as the major problems of cooperative in Greece. Regarding the strategies for enhancing commitment of members, the majority of participants highlighted the importance of improving the communication and quality of information provided by the coop to its members for building strong bond of trust and ultimately enhancing their commitment. Although, the improvement of communication takes time and requires consistent effort. Hence, cooperatives may act on employing the appropriate experts in order to improve their process of production and marketing. Strengthening the levels of expertise in the economic activities of the cooperative may assist on the satisfaction of members and enhance their commitment to the coop.
\end{abstract}

\section{RESUMEN:}

En la era de la globalización, donde la competencia está creciendo intensamente, la cooperación entre los pequeños agricultores puede ayudarlos a ser sostenibles y sobrevivir. Sin embargo, la situación de las cooperativas en Grecia se encuentra en una tendencia a la baja debido a su pobre desempeño económico, que luego se expresa por el menor compromiso de sus miembros. Para abordar el problema descrito se utilizó un estudio cualitativo compuesto por 10 entrevistados guiados con "expertos cooperativos". A través de las entrevistas, se pidió a los participantes que aclararan sus opiniones sobre dos temas principales: 1) Problemas comunes de las cooperativas griegas y 2) Sugerencias sobre estrategias empleadas por las cooperativas para mejorar el compromiso de los miembros. A través de nuestro análisis identificamos los problemas relacionados con la mala gestión de las cooperativas del pasado como los principales problemas de las cooperativas en Grecia. Con respecto a las estrategias para mejorar el compromiso de los miembros, la mayoría de los participantes destacaron la importancia de mejorar la comunicación y la calidad de la información proporcionada por la cooperativa a sus miembros para construir un fuerte vínculo de confianza y, en última instancia, mejorar su compromiso. Sin embargo, la mejora de la comunicación lleva tiempo y requiere un esfuerzo constante. Por lo tanto, las cooperativas pueden actuar contratando a los expertos apropiados para mejorar su proceso de producción y comercialización. El fortalecimiento de los niveles de experiencia en las actividades económicas de la cooperativa puede ayudar a la satisfacción de los miembros y mejorar su compromiso con la cooperativa.
KEYWORDS:

MEMBER COMMITMENT, QUALITATIVE

ANALYSIS, COOPERATIVES.
PALABRAS CLAVE:

COMPROMISO DE MIEMBROS, ANÁLISIS

CUALITATIVO, COOPERATIVAS. 


\section{RÉSUMÉ :}

À l'ère de la mondialisation, où la concurrence est en plein essor, la coopération entre les petits agriculteurs peut les aider à devenir viables et à survivre. Cependant, la situation des coopératives en Grèce a tendance à baisser en raison de leur faible performance économique, qui s'exprime ensuite par le moindre engagement de leurs membres. Une étude qualitative composée de 10 personnes interrogées et guidées par des «experts coopératifs» a été utilisée pour résoudre le problème décrit. Au cours des entretiens, les participants ont été invités à préciser leur point de vue sur deux thèmes principaux : 1) les problèmes communs aux coopératives grecques et 2) les stratégies utilisées par les coopératives pour améliorer l'engagement des membres. À travers notre analyse, nous avons identifié les problèmes liés à la mauvaise gestion des coopératives du passé comme les principaux problèmes des coopératives en Grèce. En ce qui concerne les stratégies visant à renforcer l'engagement des membres, la plupart des participants ont souligné qu'il importait d'améliorer la communication et la qualité de l'information fournie par la coopérative à ses membres afin d'établir un lien de confiance solide et, à terme, de renforcer leur engagement. Toutefois, l'amélioration de la communication prend du temps et exige des efforts constants. Les coopératives peuvent donc agir en recrutant des experts appropriés pour améliorer leur processus de production et de commercialisation. Le renforcement des niveaux d'expérience dans les activités économiques de la coopérative peut contribuer à la satisfaction des membres et améliorer leur engagement envers la coopérative.

\section{RESUMO:}

Na era da globalização, em que a competição está crescendo intensamente, a cooperação entre os pequenos agricultores pode ajudá-los a serem sustentáveis e a sobreviver. No entanto, a situação das cooperativas na Grécia encontrase numa tendência decrescente devido ao seu fraco desempenho económico, que se traduz posteriormente no menor comprometimento dos seus associados. Para abordar o problema descrito, foi utilizado um estudo qualitativo composto por 10 entrevistados orientados por "especialistas cooperativos". Por meio das entrevistas, os participantes foram convidados a esclarecer suas opiniões sobre dois tópicos principais: 1) Problemas comuns das cooperativas gregas e 2) Sugestões sobre estratégias usadas pelas cooperativas para melhorar o comprometimento dos membros. Através da nossa análise identificamos os problemas relacionados com a má gestão das cooperativas do passado como os principais problemas das cooperativas na Grécia. Em relação às estratégias para melhorar o comprometimento dos associados, a maioria dos participantes destacou a importância de melhorar a comunicação e a qualidade das informações fornecidas pela cooperativa aos seus associados para construir um forte vínculo de confiança e, em última instância, melhorar o seu comprometimento. No entanto, melhorar a comunicação leva tempo e exige esforço constante. Portanto, as cooperativas podem atuar contratando os especialistas adequados para melhorar seu processo de produção e comercialização. $\mathrm{O}$ fortalecimento dos níveis de experiência nas atividades econômicas da cooperativa pode contribuir para a satisfação dos associados e melhorar seu compromisso com a cooperativa. 


\section{INTRODUCTION}

In the era of globalization, where competition is growing intensively the cooperation between small scale farmers can assist them to achieve the needed production size for gaining market access (Bretos \& Marcuello, 2016) as well as strengthen the local community. In Greece, the roots of cooperative movement are traced back to the late $18^{\mathrm{h}}$ century and had a significant contribution to the development of the Greek rural economy (Lampos, 1999) by uniting farmers and increasing their countervailing power in the market.

Nowadays, the institution of cooperatives in Greece is facing a crisis. Since, Greek agricultural cooperatives are mostly small in size they weren't able to cope with the challenges posed by the global economic crisis of 2008 and encountered significant structural issues (Sergaki et al., 2020). The past poor management regarding production and governing procedures combined with the lack of communication of market opportunities and financial transparency, resulted into a norm of low trust to the Greek cooperative institution. Consequently, the trust and commitment of young Greek farmers to agricultural cooperatives was deteriorated, since they report that they don't have incentive to enter or retain their membership to a cooperative organization (Kontogeorgos et al., 2017). Hence, the downward course of the cooperative sector in Greece, among other things, is highly related to the disconcerted commitment of members to the institution of Greek agricultural cooperatives.

However, the vast majority of scientific studies on Greek agricultural cooperatives are focused on their financial performance and economic survival, while member commitment is presented as of secondary importance. Members' commitment to the coop is essential in order to form a common front for farmers as a competitive force against the increased competition of the globalized agro-food markets (Novkovic, 2008), with scale or scope economies.

In that sense, following recommendations by Kontogeorgos et al. (2017) regarding the importance of member commitment and the formulation of strategies for enhancing it, this paper addresses the gap in the literature with a qualitative study to identify the issues related to low levels of member commitment and the strategic decisions of coops for incentivize members to become more active, more committed and attract new members. Specifically, the research question is expressed as follows: Which are the main factors dictating the loss of commitment to Greek agricultural cooperatives and what strategies can be utilized for enhancing it? In this study the research question is addressed with a qualitative study with evidence collected through interviews of experts that have long experience in cooperative operations.

This paper's contribution is demonstrated by a qualitative method approach on opinions of "experts", related to the cooperative sector, for identifying strategies that aim on enhancing member commitment, a topic which has not received much explicit attention in the Greek cooperative academic literature. Using data provided by experts with long experience and relating them to the theoretical background of international literature, the qualitative study provides information on how cooperatives can formulate strategies to enhance their member's commitment subject to the diverse member motivational priorities such as economic benefits, additional services such as expertise in the planning of production and marketing, need for establishing market power and arising opportunities, structure of governance and communication quality. In particular, better price than the competition, vertical integration and specialization of production along with market access and stability are factors of high significance and can be further utilized as strategies to motivate members to retain their commitment to the collective enterprise.

The paper is organized as follows. Section 2 provides a literature background of the main themes of this study: a) The importance of member commitment, b) The importance of member satisfaction, c) Common problems related to the member commitment of agricultural cooperative structures in Greece, as well as, d) A framework of the factors influencing the member's satisfaction and long term commitment to the collective enterprise that could be utilized as cornerstone for the formulation of strategies for enhancing member commitment. The methodology of this study is described in Section 3. Section 4 presents the interpretation of the findings according to the information provided by cooperative experts on the explanation of common cooperative issues and their opinion on the strategies for enhancing commitment in Greek agricultural cooperatives. Finally, Section 6 presents the conclusions of this study, including a discussion of future research directions. 


\section{BACKGROUND}

\section{Common cooperative issues}

On the other hand, the lack of commitment of cooperative members may result into a series of issues. By reviewing cooperative literature (Staatz, 1987; Grashuis, 2018; Van Dijk et al., 2019, pp. 39-45), we identified six different categories of collective action problems which are highly related to member commitment, those are: (i) the freerider problem, (ii) the horizon problem, (iii) the portfolio problem, (iv) volume problems, (v) the control problem, and (vi) incentive problems. The reasoning behind problems connected with low commitment is manifested in the heterogeneity of member's preferences and attitudes on cooperative operational structure, as also to personal characteristics and objectives such as farm size, risk attitudes, wealth and experience.

The above described issues predict certain behaviors that are stimulated from the loss of commitment of members to the collective enterprise. An example of member behavior resulting from low commitment is manifested by the non-participation attitude in the decision making assemblies (Kontogeorgos et al., 2017). This behavior is rooted either in the dissatisfaction of the member with the ways the cooperative conducts business, or when the member fails to realize the cooperative as a business of his own.

\section{Factors influencing member commitment}

There are several factors that affect the commitment of the member to the collective enterprise. These factors act as motives for a member and are mostly rooted in the benefits from intra-organizational attributes of the cooperative structure. The commitment of members is highly influenced by their individual attitudes on certain cooperative attributes (Dakurah et al., 2005). Grashuis \& Cook (2018), defined satisfaction of members' as a positive impact on the utility members' receive, from a diverse set of factors, when they conduct business with the co-op. They conclude that satisfaction is not only expresses the perceived positive impact in period $t$, but also predicts the members' behavior in period $t+1$ regarding his commitment to the coop.

Member commitment is an individual attitude driven by the members' utility subject to their preferences of certain cooperative attributes (Kalogeras et al., 2007; Morfi et al., 2015) and therefore can be influenced by the implementation of a wide spectrum of strategies adopted by the co-op (Trechter et al., 2002). Those strategies are diversified regarding their utility as motivational factors based on specific cooperative attributes, which are explained below. Namely, the relative coop attributes utilized in this study for formulating the strategies for enhancing commitment are: Economic benefits, Additional services, Market power, Cooperative governance, Communication, Control and Cooperative ideology.

\section{Economic benefits}

According to Fulton (1999), the reasoning behind the choice of each economic agent to participate in a business structure is found in the benefits they desire to obtain from their participation. Thus, economic benefits provided by the coop can be argued to be the main motive for farmers on entering and remaining in the coop. By reviewing the international literature (Nishi \& Kumar, 2011; Liebrand \& Ling, 2014), we observed that monetary benefits and the stability of economic transactions provided by the coop, constitute significant factors for the satisfaction and long term commitment of members with the collective business. Price is the most evident determinant of demonstrating the farmers' commitment to the coop, since the members, as entrepreneurs trying to maximize their wealth, will always choose the organization that provides the best price for their produce (Fulton, 1999). Furthermore, the importance of cooperatives is found on the capability to vertically integrate the production by providing cheaper access to materials, supplies, transportation and storage facilities (Morfi et al., 2015), which significantly improves individual cost efficiency.

\section{Additional services}

Cooperatives are not only about creating economic benefits for the members, but provided them with the appropriate knowledge and expertise in order to expand or improve their operations. Specifically, cooperatives hire experts in order to fulfill the needs of members in terms of quality services (Tilahun, 2007) and technical support (Kalogeras et al., 2007). Consequently, this may influence members toward a more favorable perception of their membership to 
the organization. Additionally, high involvement to the coop give members the opportunity to acquire experience and expertise through participation in learning activities organized by the coop (Verhees et al., 2015), such as training seminars. Furthermore, farmers' training through coop activities positively affects their wellbeing and enhances their satisfaction with the coop (Ishimwe et al., 2016). Consequently, increased satisfaction may inspire loyalty to the farmers and lead them on attaining higher levels of commitment (Kokotas et al., 2016).

\section{Market power}

In contemporary times the role and business orientation of agricultural cooperatives is shifting. According to Kalogeras et al. (2007), members preferences on the strategic attributes of the coop are toward a more entrepreneurial and market-oriented organization, which exploits market intelligence and coordinates product quality to reach the expectations of existing and potential market segments. Several researches (Van Dijk, 1999; Cook \& Chaddad, 2004; Kalogeras et al., 2007) mention the adoption of customer-driven strategies from cooperatives, similar to those utilized by IOF organizational structures, to achieve better economic performance and satisfy the ambitions of their members and ultimately keep them committed. Jensen (1990) point out the high motivational importance of the function of the cooperative to provide an assured marketing channel to members, which has a significant impact on their attitude toward the collective enterprise. In addition, coops provide a safety net to small scale farmers, while by marketing their produce through the cooperative they are not obliged to bare the foul cost and risk of their economic activity (Van Dijk et al., 2019, p. 30). This refers to a good organization of the marketing process.

\section{Cooperative governance}

Following the assumptions of Verhees et al. (2015), there are three models of cooperative governance and their diversification is found on the agents and committees that have the first role in managing the collective business. The common ground between cooperative governance models is observed in the delegation of control rights and authority to the $\mathrm{BoD}$, cooperative experts or a small group of cooperative patrons respectively. In all three models, members hold ex post control rights which are exercised in cases that the authority agents lead the coop to poor performance. In addition, Iliopoulos and Theodorakopoulou (2014), highlight the necessity of conflict resolution mechanisms, for resolving conflicts within the members group quickly and in a commonly acceptable fair way, as a prerequisite for the "healthy" management of collectively-owned enterprises.

\section{Communication}

However, member's involvement through participating actively in governance procedures provides significant individual benefits by reducing the asymmetry of information between coop management and members (Verhees et al., 2015). Good quality of information may assist on reducing transaction costs and strengthens social relationships between members and the coop by enhancing the feeling of belonging to a social group (Barraud-Didier et al., 2012). In addition, when members acquire sufficient and accurate information may result in a competitive advantage for the coop over other IOF's because they identify opportunities faster and receive market information before their competitors (Boned \& Mutuel, 2006). According to Trechter et al. (2002), strong communication between members, and members and the BoD have a significant impact on enhancing the members' commitment to the objectives and goals of the coop, since members identify the cooperative as a business of their own.

\section{Control}

The governance of agricultural cooperatives is often commissioned to a small group of members or non-members. Fulton and Giannakas (2007) noted that the success of cooperative governing instruments is highly dictated by the type of leadership the members elect. If members perceive that agents in charge take decisions to fulfill their personal agenda instead of acting on their behalf, their commitment may be diminished (Fulton \& Giannakas, 2001). Bhuyan (2007) discusses the members' involvement in committees for controlling the decisions of coop management as of great significance for the members' satisfaction with the cooperative. The involvement of members in meeting and assemblies has been proven to be vital for the performance of the coop due to its impact on increasing the efficiency of control and governing mechanisms (Österberg \& Nilsson, 2009). The increased involvement in cooperative governance procedures, assist members to identify themselves with the common goals of their cooperative and strengthens their sense of affective commitment (Barraud-Didier et al., 2012). 


\section{Cooperative ideology}

According to Fulton (1999), the member will conduct business with the partner that will provide him with the better outcome. Consequently, the member's commitment to the collective enterprise is dependent on how she perceives her membership to the coop. On the contrary, Morfi et al. (2015), highlighted that the majority of "loyal" Finish cooperative members are not considering their membership relationship with the coop as purely business oriented, due to their understanding of the long term tangible and intangible benefits of doing business collectively. Thus, they demonstrate their sense of cooperative ideology.

\section{METHOD}

In order to address the described problem, we employed a qualitative analysis consisted of 10 guided interviews of cooperative experts (Trinczek, 2009). The interviews were conducted in a semi-structured approach with the provision to the participants of an interview guide. The interviews addressed a range of issues related to diminished member commitment in Greek agricultural cooperatives according to the participants' experience associated to the cooperative field. The participants were asked for their opinion on the issues contemporary Greek cooperative organizations are facing, the reasoning behind these issues, and finally their suggestions for the most optimal and applicable strategies aiming on enhancing the commitment of farmers to the Greek agricultural cooperatives, both individually (in a single coop) and institutionally (in Greek cooperatives as a form of institution).

\section{Participants}

The interviewees were chosen either for their knowledge and experience on the cooperative organizational structure, for their knowledge and experience in the Greek agro-food market or for their academic expertise in the field of cooperative studies. The sample group was divided into three different sub-groups. The Academics sub-group was consisted of $4(40 \%)$ individuals whose work provided significant value in the Greek and International cooperative literature. The Cooperative Elected Representatives group (mostly members that served on the BoD of cooperatives located in Crete, Greece) is represented by $4(40 \%)$ people mostly from Cretan cooperatives with extensive experience in cooperative governance. While the cooperative consultant experts sub-group was represented by 2 $(20 \%)$ individuals, which have extensive experience in the Greek state mechanisms and continuously monitoring Greek agricultural cooperative businesses both domestic and overseas. This classification is made to enable the indepth interpretation of the concepts and ideas by taking into consideration the diverse roots of each participant's background which may dictate his/hers approach to the strategies for enhancing member commitment.

\section{Data collection}

An interview guide was developed containing open-ended questions along with some general background questions, which illustrated the basis of all interviews. In the beginning, the interviewees were asked whether we have their permission to record the interview. The interviewed experts were provided with a copy of the interview guide and general information about the study. Where possible the interviewees received the interview guide several days earlier to enable them to reflect on the issues raised. During the arrangement of the guide to be sent to the interviewees and the arrangement of date and time for the interview, the first author (as interviewer) provided with the opportunity to interact with the respondents and establish a base of trust before the interview conducts.

Key questions outlined in the guide were:

1) What are the contemporary problems Greek coops are facing?

2) Which of the problems of Greek coops are related to the relationship with the members?

3) Which strategies you believe are very important for enhancing commitment in Greek coops?

4) Which strategy will you implement if you acted as president of the BoD, to enhance commitment in Greek coops?

In order to further investigate suitable strategies for enhancing member commitment we created an inventory of proposed strategies based on international literature for factors that influence member commitment. The expert interviewees were asked to evaluate the proposed strategies in a 3-point Likert scale ( 1 =Not Important, $2=$ Important, 
$3=$ Very Important). The interviewees had the opportunity to propose an alternative strategy, than those presented by the authors, if they had the belief that none of them fitted their vision for enhancing commitment. After the evaluation of the strategies, the interviewees had to explain why they chose a strategy as "Very Important". The present strategies and their reasoning are presented below in Table 1.

\section{Table 1: Strategies for enhancing commitment}

\begin{tabular}{|c|c|c|}
\hline Strategy & Sample Items & Retrieved from \\
\hline Economic Benefits & $\begin{array}{l}\text { Increasing the value of economic benefits for the } \\
\text { member by providing better prices for their product, } \\
\text { cooperative dividends and improving cost efficiency } \\
\text { (better price for fertilizers, medicines and production } \\
\text { materials). }\end{array}$ & $\begin{array}{l}\text { Fulon, (1999); Nishi and Kumar } \\
\text { (2011); Liebrand and Ling (2014) }\end{array}$ \\
\hline Additional Services & $\begin{array}{c}\text { Enhancement on the additional services provided by } \\
\text { the coop such as technical support (hiring experts) and } \\
\text { training seminars. }\end{array}$ & $\begin{array}{l}\text { Kalogeras et al. (2007); Tilahun, } \\
\text { (2007); Ishimwe et al. (2016) }\end{array}$ \\
\hline Market Power & $\begin{array}{c}\text { Strengthening the position of cooperatives to the } \\
\text { market by increasing bargaining power with market } \\
\text { oriented strategies (Provide assured marketing } \\
\text { channels, building strong brand name, increasing } \\
\text { product and services differentiation). }\end{array}$ & $\begin{array}{c}\text { Jensen (1990); Van Dijk (1999); } \\
\text { Cook and Chaddad (2004); } \\
\text { Kalogeras et al. (2007) }\end{array}$ \\
\hline Cooperative Governance & $\begin{array}{l}\text { Reconstruction of the governance structure of } \\
\text { cooperatives and cooperative rules (e.g. the approach } \\
\text { on how to solve disagreements between members) }\end{array}$ & $\begin{array}{l}\text { Iliopoulos \& Theodorakopoulou } \\
\text { (2014); Verhees et al. (2015) }\end{array}$ \\
\hline Communication & $\begin{array}{l}\text { Increase communication between members and } \\
\text { between members and the BoD to reduce asymmetry } \\
\text { of information (more frequent briefings on market } \\
\text { information) and increase economic transparency. }\end{array}$ & $\begin{array}{l}\text { Trechter et al. (2002); Bijman and } \\
\text { Verhees (2011); Verhees et al. } \\
\text { (2015); Van Dijk et al. (2019) }\end{array}$ \\
\hline Control & $\begin{array}{l}\text { Increase control and evaluation both from member } \\
\text { committees to the BoD and from the BoD to the } \\
\text { members in order to establish a mechanism for } \\
\text { ensuring that coop acts on behalf of the members and } \\
\text { vice versa. }\end{array}$ & $\begin{array}{l}\text { Trechter et al. (2002); } \\
\text { Bhuyan (2007) }\end{array}$ \\
\hline Cooperative Ideology & $\begin{array}{c}\text { Promote the added value of cooperation and empower } \\
\text { the members' sense of cooperative ideology through } \\
\text { educational programs. }\end{array}$ & $\begin{array}{l}\text { Flecha and Ngai (2014); Morfi et } \\
\text { al. (2015); Verhees et al. (2015) }\end{array}$ \\
\hline
\end{tabular}

Source: Author's elaboration

All ten interviews where audio-recorded. The interviews were conducted via phone calls in November 2020, while coping with the restrictions and measures for managing Covid-19 pandemic. Notes made by the first author during the interview were kept also. The average duration of the interviews was estimated at about 45-60 minutes per respondent.

\section{Data analysis}

The analysis of the data was conducted by examining and interpreting both the notes made by the author and the recordings of the interviewee's statements. Further, the transcripts were subjected to systematic verifiable analysis of themes and ideas. The base themes were divided to subcategories which were assigned with codes indicating their relation to particular larger concepts and ideas. Coding was then cross-checked and verified with the co-authors.

\section{Trustworthiness}

In order to establish critical methodological precision to qualitative studies substantial attention should be given to the reliability and validity of the gathered data (Liedtka, 1992, p. 172). As this study is concerned, a plethora of factors may have influenced the validity and reliability of the findings. The sample selection was made in personal base through personal contacts and introductions which in turn reduced our ability to investigate a random sample of respondents. 
In this study, participants were encouraged to reflect on their own most recent or current experience, related to cooperative institutions, as well as the incidents that happened in the past and they considered to be as more accurate to address the scope of this study. In the same time, through probing questions and field notes, the interviewer attempted to extract as much detail as possible from both their actual and emotional responses. The fact that the participants were to encourage to present "concrete incidents that are directly meaningful" to them personally illustrates the most suitable method to enhance this type qualitative research on field experts (Liedtka, 1992).

Finally, a crucial stage for the validity of the results is found on the presentation and interpretation of the findings. Especially, while the subject cooperatives as an area of investigation is complex, the responses of participants should be taken into consideration with relation to their personal experiential background, for each participant separately. In addition, an obstacle which may occur and diminishes validity in qualitative research is observed in the lost contextual detail during the transcription process, while transferring the answer from recordings to text. According to Liedtka (1992, p. 171), sufficient detail is needed to be included in the presentation of the findings to ensure that the respondents speak "in their own words".

\section{PRESENTATION AND INTERPRETATION OF THE FINDINGS}

Two overall themes were emerged after analyzing the data. Firstly, the identified issues Greek cooperatives are facing were more or less standardized despite the variation between the different participant's background and nature of involvement. The second theme to emerge was variety in individual responses on how to address the problems of low commitment of members to Greek agricultural cooperatives. The description of the data which follows encompasses, firstly, the identification of common major issues Greek agricultural coops are facing according to the participating experts experience, under sub-headings for each type of issue. Secondly, we summarize the suggestions made by the cooperative experts toward the enhancement of member's commitment in Greek coops.

\section{What short of problems contemporary Greek coops are facing?}

Great uniformity between interviewee's responses was evident in the description of the common major problems of cooperatives regarding their financial sustainability and relationship with members. Interestingly, and consistently with our conjecture of the bidirectional relationship between commitment and cooperative's economic performance, participants in their majority related the diminished commitment of Greek farmers to cooperatives with the poor economic performance of the later. In our analysis we observed three sub-categories of issues faced by cooperatives resulting in poor economic performance and weakening their competitive position in the markets. Thus, poor economic performance combined with the low levels of cooperative ideology result in the diminishment of member's commitment.

\section{Common characteristics of Greek cooperative members}

There are common characteristics of Greek cooperative members which have a significant impact in the line of operations of cooperatives. The small farm size is a common issue and is closely related to the low levels of competitiveness of Greek coops, since the increased globalization of markets demand exponentially larger quantities. As a result cooperatives with small production volumes cannot meet the demands of business contracts both domestic and abroad.

"The allotment of the average Greek farmer is found to be small, the production sizes are also small. These contribute to a problematic profile of entrepreneurship and competitiveness in the primary sector".

"The main problem facing Greek cooperatives is fragmentation; economies of scale cannot be pursued".

In addition to the small farm size, several interviewed experts raised the issue of low expertise level of Greek farmers. According to $70 \%$ (7 out of 10) of participants, the level of expertise for the individual farmer in a cooperative is considered to be a determinant for achieving the needed levels of production and can further provide better insight on the decisions related to the product's marketing procedures.

"The problems that Greek cooperatives are facing in my opinion are the problems that arise, and have to do, with marketing process; there is lack of expertise on finding the suitable markets to channel their products". 
"The cooperative is currently unable to meet the requirements of high impact marketing procedures in a market that is highly competitive".

Regarding the personal characteristics of the members, cooperative experts with experience in the consulting services for cooperatives raised the issue of heterogeneity among members' preferences which resulted into "horizon problems" and lack of cooperative ideology.

"An equally big problem of Greek cooperatives is the heterogeneity in the member's ideology characteristics and preferences".

“...farmers never felt the cooperatives as their own business. As a result, they didn't have the inceptive to invest in the further development and growth of the cooperative due to differentiated horizon perspectives".

\section{Problems of cooperative management}

In the past, the cooperative institutions were highly related with the Greek political scenery. Due to the impact cooperatives had in the rural communities many political parties got involved in their organizational affairs. According to $40 \%$ of the participants ( 4 out of 10 ) the involvement of political parties in agricultural cooperatives is highly related with the diminishment of Greek farmers trust to the cooperative institutions.

"Vote-buying behaviors brought great distrust and alienated the people from the cooperative institutions".

"The problems of mismanagement sprang from the intervention of political parties and pushed the cooperatives to operate outside the basic cooperative principles".

"The governmental interventions that happened in the past in the cooperative enterprises sector turned the cooperative effort into purely contracting activities. In other words cooperatives operated outside of their basic principles and acted as middlemen for farmers to market their products".

All of the participants (10 out of 10) highlighted the significant contribution of problems rooted in the dysfunction of the cooperative's management, both organizational and financial, for explaining the low levels of member commitment in Greek agricultural cooperatives.

"Greek cooperatives are facing many problems related to their organizational and operational management, which results in diminishing the trust of their members".

"The poor quality of communication and information provided by the coops may be a cause of the diminishment of member's trust".

The ineffective management on both production and marketing results into weakening the position of cooperatives in the market and was found to play a crucial role in the diminishment of their members' commitment. Therefore, it acts as a disincentive for farmers to conduct business with the cooperative and pushes them to the private sector.

\section{Attitudes of members}

Other than the problems rooted in the diversity of the members' personal characteristics and the poor quality management of cooperatives, significant problems occur due to problematic behaviors of members. Specifically, by taking into consideration the fact mentioned above that members do not fully understand the cooperative as their own business members of Greek cooperatives often develop "free-rider" behaviors and non-participation attitudes.

The participant's statements regarding the frequency of the free-riding phenomenon was found to be differentiated relative to the nature of their involvement with cooperative business affairs. Specifically, participants that are related to small-scale cooperatives $(30 \%, 3$ out of 10$)$ referred to the "free-rider" problem as not significant since they report that they never experienced extreme behaviors of free riders.

"Also, there is always the risk of the free rider (...) but members in our cooperative, due to the small size of the cooperative I suppose, has never shown such behaviors in the past". 
On the contrary, participants involved in the scientific research of cooperative structures referred to the "free-rider" phenomenon as of crucial importance for the viability of both small and big size cooperatives.

"Also regarding the members we can observe opportunistic behaviors in some degree, illustrated by some of the members (e.g the free rider problem). In my experience, these can occur in both small and large cooperatives".

Regarding the non-participation of members, uniformly for all expert interviewees (100\%, 10 out of 10), mentioned that its low levels explain the poor performance of Greek cooperatives. The non-active participation of members is mostly due to their lack of understanding the cooperative as their own business.

"A very important problem that Greek cooperatives have to face is that their members' do not feel the cooperative as their own business and therefore they do not participate in decision-making processes".

"A major problem we faced as a cooperative was found in the active participation of the members in the assemblies. Out of the 220 members in the assemblies, about 40 actively participate".

All participants clarified that the members' non-active participation behaviors are resulting from their low levels of commitment and can be expressed as a matter of member's opportunistic behavior. On the other hand, the low quality of information provided by the coop combined with the member's low levels of training and education on cooperative affairs may result to their alienation with their coop and ultimately drive their non-participating attitude.

"The first major problem of cooperatives lies in the fact that there is no participation of members because their wounds have not healed from the mismanagement of the past".

"The reason why producers do not participate is due to the combination of management problems with the reduced financial results which lead to a lack of interest for the cooperative on behalf of the member and ultimately discourage his active participation".

\section{Strategies for enhancing commitment}

In order to address the described problems of diminished trust and commitment illustrated by coop members, the interviewees evaluated several strategies aimed on different cooperative attributes. Table 2 depicts the average score of the participants for all eight strategies formulated by the authors.

\section{Table 2. Strategies for enhancing commitment}

\begin{tabular}{|l|l|l|l|l|}
\hline $\begin{array}{c}\text { Strategies for } \\
\text { enhancing } \\
\text { commitment }\end{array}$ & \multicolumn{1}{|c|}{ Academics } & \multicolumn{1}{c|}{$\begin{array}{c}\text { Cooperative BoD } \\
\text { Members }\end{array}$} & Counselors & \multicolumn{1}{|c|}{$\begin{array}{c}\text { Total } \\
\text { Sample }\end{array}$} \\
\hline Economic Benefits & 2,25 & 3 & 1,5 & 2,25 \\
\hline Additional Services & 2,5 & 2,25 & 1,5 & 2,08 \\
\hline Market Power & 2 & 3 & 2,5 & 2,5 \\
\hline Cooperative Governance & 2,75 & 1,75 & 1,5 & 2 \\
\hline Improvement of Communication & 2,5 & 2,75 & 3 & 2,75 \\
\hline Control & 2 & 2,75 & 2,5 & 2,42 \\
\hline Cooperative Ideology & 2,25 & 2,5 & 3 & 2,58 \\
\hline
\end{tabular}

Source: Author's elaboration 
The strategy that was evaluated as the most important among the total sample of the participants was the one referring to the improvement of communication between the coop management and the members. Other than the improvement of communication and quality of information provided by the coop, the interviewee's answers on the cooperative attributes where diversified according to their type of involvement experience with the cooperative sector. The sub-group of Academics evaluated as the most important strategy the restructuring of cooperative governance as of higher importance to the remaining strategies. As for the interviewees that served as members in cooperative BoDs' are concerned, they highly evaluated in their absolute majority the sufficient economic benefits and the enhancement of cooperative's market power as the strongest strategies for motivating the members to sustain their commitment. Finally, the sub-group of counselors, which was the shorter among the three sub-groups, evaluated as very important the strategies related to the improvement of communication, and the enhancement of the member's cooperative ideology.

\section{Economic benefits}

Sufficient economic benefits provided by the coop is a factor commonly mentioned as of great significance for the enhancement of the member's commitment, since they ensure the wellbeing of the member and his/her family. All of the participants highlighted the necessity of the provision of fair prices for the member's produce as a prerequisite for the member's commitment to the coop. In addition the provision of cooperative dividends when there is surplus and the cooperative shop discount where mentioned as of supplementary significance for motivating the member to be more committed.

“...in order for a member to be loyal he must obtain financial benefits and in particular fair prices, this is very important”.

"Relative to the production supplies (fertilizers, equipment, consumables etc.) the cooperative tries its best to provide them to farmers at very attractive prices and thus is an incentive for a producer to stay committed or become a member of the cooperative. Members have better prices than non-members".

"Financial results translated into surplus distribution, or the provision of immediate benefits through low or high prices may assist on motivating the members to be more committed".

Although, the provision of economic benefits through the cooperative organization is important, it has to be accompanied with the appropriate educational stimulus for the member and enhance her understanding on the cooperative mission. Otherwise, the member will treat the cooperative only as a commercial partner and will not sustain his commitment in times of poor economic performance.

\section{Additional services}

The significance of the cooperative for the members can also be found in the value of the additional services provided. The majority of the participants $(70 \%, 7$ out of 10$)$ highlighted the significant impact of additional services provided by the coop on motivating the members to sustain their commitment to the collective venture. The coop should provide functional solutions to the problems arising from the farmers' low levels of professional expertise. The effort by the coop should be made on solving production issues (eg. counseling for the suitability of crops in terms of market demand and soil conditions, plant diseases, reducing the cost of production by introducing contemporary methods etc.).

"Producers come and ask very often about technical issues with the crop so it is very important to have specialized staff in the cooperative for the technical support of the members".

"The satisfaction of members by cooperatives may be enhanced by providing high level of services (...) this may inspire members to understand that acting inside a coop business is for their own benefit".

"I think that the connection with the producers can be achieved by the specialized agronomist with constant support and assistance in the consulting part". 
On the other hand, an interviewee opposed to the additional services provided by the coop to act as motives for inspiring commitment. Since, hiring specialized staff will significantly increase the cooperatives costs and consequently this action will not be feasible in the long term.

"Hiring specialized employees to advise the farmers may not support the whole spectrum of the production and therefore is going to raise the costs for the cooperative without providing increased efficiency. It is better for producers to turn to other private scientists as they choose..."

\section{Market power}

The achievement of strong economic benefits springs from the combination of producing a product of good quality and furthermore from the effectiveness of the marketing process. Especially, according to all the member of the BoD members sub-group (Table 1) increasing the cooperative's market power is "Very important" for enhancing the member's commitment. Making contracts that will absorb the whole volume of production and finding markets that will provide stable prices for the products were among the activities mentioned that will motivate members to sustain their commitment to the coop, since it will provide security for marketing their products.

"Having an organized product promotion department like a good brand name is very important and is an incentive for someone to be a member of the cooperative".

"For enhancing the member's loyalty the first is to formulate a business strategy by better organizing the marketing mechanisms and the existence of strategic planning, this may provide proof to members and keep them committed".

“...the ability of the coop to absorb the entire range of products and place them on the market $(\ldots)$ Effectiveness and stability of distribution channels, may strengthen the farmers' trust and enhance their commitment to the coop".

"We try to help in the part of marketing as much as possible, to organize an action plan for the marketing of the product of the cooperative. In other words, we aim on building a strong name in the foreign market in which the producers can depend on".

Evidentially, Greek cooperatives mostly due to their small sizes are not able to meet the increased requirements of big supply chains. The increase in the market power of cooperatives in the globalized context is very important but extremely difficult to achieve and a lot of effort is required.

\section{Cooperative governance}

Effective management is required for the satisfaction of both the members' needs and the achievement of the cooperative goals. According to $70 \%$ of the participants ( 7 out of 10), the management of Greek cooperative should be restructured toward the fulfillment of members' needs. Capable individuals in the according position in the cooperatives leadership is found to be crucial for sustain the member's commitment. In addition, coop leadership should inspire trust to the members in order for them to participate more actively in the coop affairs and increase its social capital value.

"There must be a reconstruction of cooperative rules and ways of administration, separation of powers and a framework for cooperation between them, in order for the members to have trust in the organization".

“...the cooperative must investigate the problems of its members and to propose appropriate solutions. (...) This could provide a basis for increasing member satisfaction and consequently their commitment, enhance the members feeling that the cooperative is above their problems and takes care of them". 
"Firstly, cooperative leadership should be consisted of people who have knowledge on practice of management as well as marketing, to provide fair economic results. Secondly, they should treat the members with respect, exploring their needs and problems in order to provide solutions. If all this is done the member will gain confidence and will be able to understand potential poor economic results".

\section{Improvement of communication}

In contemporary times information is essential for coping with the requirements of the increased competition of globalized markets. Furthermore, as highlighted by the majority of participants $80 \%$ (8 out of 10), transparency in the cooperative activities is a prerequisite for the sustainability of its successful operation. Additionally, is the leadership's obligation to consistently try to improve the quality of provided information and value of communication, in order for the member to sustain his commitment to the collective enterprise.

"Cooperatives should seek ways or communication techniques that will allow the members to understand the decisions of the BOD and be persuaded that the cooperative management act on their behalf".

"Mainly we focused on enhancing the information for the production procedure in order to inspire motivation for our members".

"Something I consider very important is that the cooperative should not to be arrogant towards the members and to inform them at all times about WHAT the coop does and HOW it does it!".

Specifically, the communication techniques mentioned by the participants were mainly focused on: organizing production seminars, information booklets and the emergence of electronic platforms (websites), where members can acquire all the desirable information. These methods are aiming on enhancing the expertise level of members as well as establishing that the cooperative act on their behalf.

"Enhancing communication between members is much more important especially for their commitment. If the market power falls and the communication between the $\mathrm{BoD}$ and the members is poor the member's trust and commitment to the coop will be diminished".

“...we printed an information leaflet on the basic principles of cultivation to decongest the confusion in the information in order to better inform the producers $(. .$.$) we have established an information network to which$ the producer can turn at any time and receive the information he needs".

"To enhance commitment I suggest the emergence of a software (platform) that will allow members to have access anytime to basic information related to cooperative matters in terms of production, economic state and management".

As depicted in Table 1, the strategy referring to the improvement of communication as a motive for stimulating commitment was evaluated as the most important $(\geq 2,5)$ by all the three sub-groups of expert interviewees with an average score of 2,75 .

\section{Control}

The cooperative operations are defined from the farmer's willingness to cooperate with others in order to obtain the benefits he/she requires. However, control mechanisms consists a necessity for ensuring the proper functioning of all the arrangements inside the cooperative framework. On one hand the cooperative decisions should be controlled by member committees consistently. Ensuring the proper function of the cooperative management by members was found to be significant for the member's participation in the cooperative assemblies. 
$40 \%$ of the participants (4 out of 10) mentioned the intensification of control in cooperatives as essential for its proper function.

“...it is necessary for the member to control through committees the activity of the governing council for its attitude towards the farmers and the cooperative as a joint venture. In other words to control based on the objectives".

"Assigning management responsibilities to the members of the cooperative like participating in committees and other activities will give them a sense of ownership for the cooperative venture".

On the other hand the cooperative leadership should control their members for keeping their promises and not choose to free-ride, both in terms of quality and quantity provided to the coop. While, the farmers should respect their covenant in order to meet the requirements of business contracts with external partners. Ultimately, strong business contracts will provide significant economic benefits which are crucial for the viability of the coop.

“...the second is to intensify the control over the farmers for the observance of the regulations, which will result from the consistency and the organization in the governance of the cooperative".

"It is very important to have control by the Board of Directors to the members for ensuring the fulfillment of commercial arrangements and compliance with the coop rules".

\section{Cooperative ideology}

As the cooperative ideology of members' is concerned, the answers of the participants were diverse regarding its level in Greek coop members. According to Table 1, the sub-group of cooperative counselors referred to the enhancement of cooperative ideology as the most important strategy for enhancing commitment. Specifically $40 \%$ of interviewees ( 4 out of 10), mentioned that by educating the farmers by promoting cooperative ideology will drastically empower their commitment to the cooperative. In this sense, members with better understanding of the cooperative principals will be more understanding in times of poor economic performance and will not turn to the private sector when the prices are lower for the cooperative. They suggested that cooperatives should constantly seek ways to educate their members toward the importance of the cooperative structure through educational seminars and activities.

"Cooperatives should educate their members, in the sense of explaining to them what a cooperative is. I have had the opportunity to talk to people who were preparing to form a cooperative and through the conversation I realized that people did not know what a cooperative is".

"Given the increasing globalization, things are becoming more and more difficult. The members must understand that the cooperative is the vehicle that will lead it to ensure its prosperity in order to face the globalization of markets".

"The strengthening of cooperative ideology is very important because the member must understand that the cooperative is also his, his own business. I was very impressed when I realized that they did not realize it. They treated the coop like a shop and in case someone else gave them a better price then they would sell their products there".

\section{CONCLUSIONS}

By briefly examining the interviewees' answers we realized that commitment of members in Greek cooperatives is diminishing. This is mostly due to the mismanagement issues of the past and the present weak competitive power of the cooperative in the context of globalized markets. Consequently, opportunistic behaviors of members arise 
and create big confusion to the cooperative operations. Those behaviors are rooted either in the dissatisfaction of the member with the organization of commercial activities, or when the member fails to understand the coop as his/hers own business. In both situations is the cooperatives objective to act on behalf of the members and provide proof of doing so, in order to increase the member's sense of commitment. The provision of strong economic benefits, as suggested by the sub-group of BoDs members, is a strong motivational factor for inspiring commitment, although it is highly dependent on external environmental factors which the coop cannot easily predict. Thus, the cooperatives in Greece in order to enhance the level of commitment of their farmers have to implement strategies toward two key directions.

Firstly, as highlighted by the total sample of interviewees and specifically the cooperative counselors, the cooperatives should emphasize on increasing the quantity and quality of communication with their members in order to build a strong bond of understanding with them. This could provide both opportunities and stability, since members will be able to realize market opportunities and act toward them. In the same time, by increasing the value of communication, members may show greater understanding in times that the cooperative financial results will not be as well as expected. A matter of great significance to the strategy aiming on enhancing communication with members is the employment of educational seminars for informing member and non-member farmers about the benefits of cooperation and its utility as a mean to overcome the challenges posed by globalized markets and increased competition. This could provide contingencies on shielding the members' sense of commitment toward the cooperative by fully understanding that the cooperative is a business of his/her own. In other words, high levels of commitment may be achieved by strengthening the member's sense of cooperative ideology. Secondly, cooperative should act toward the training and education of farmers on matters of both production and marketing operations. Consequently, members will expand their specialized knowledge and they will be more capable on organizing their economic activity toward the achievement of the common goals.

Finally, regarding the coop management, following the suggestions made by academics of cooperative research field we draw the conclusion that the cooperative should be staffed with specialized professionals with knowledge on the production and marketing procedures as well as the financial management. By taking into consideration the good quality of the soil-climatic conditions of Greece combined with the modernized techniques provided by the above mentioned strategy, the cooperatives could focus on addressing specific market segments with high standards in quality of agricultural products. Hence, if the cooperative enhances its business operations and methods of communication, the members will be able to fully understand the significance of their membership in the collective enterprise. In this sense, their commitment will be enhanced and they will acquire significant motivation for further investing in the cooperative. The establishment of proper functional mechanisms may encourage members to increase their participation as well.

The themes identified in this study also have implications for further academic work in the cooperative research area. Since the number of cooperative experts interviewed was small, further quantitative studies need to be employed to examine the relevance of the themes in larger populations. The opinions of members of cooperatives need to be investigated from both qualitative and quantitative perspectives to identify the relevance of the themes identified here from the member's perspective. The findings of studies similar to this one would inform practical responses to the low commitment problem of Greek cooperatives and indicate whether the tentative suggestions we have made above can be useful to differentiated cultural contexts. 


\section{REFERENCES}

Barraud-Didier, V., Henninger, M. \& El Akremi, A. (2012). The Relationship between Members' Trust and Participation in Governance of Cooperatives: The Role of Organizational Commitment. International Food and Agribusiness Management Review, 15(1), 1-24.

Bhuyan, S. (2007). The 'people' Factor in Cooperatives: An Analysis of Members' Attitudes and Behaviour. Canadian Journal of Agricultural Economics, 55, 275-98.

Boned, O. \& Mutuel, Crédit, (2006). Annual Report. Europe Rabobank, ICBA.

Bretos, I. \& Marcuello, C. (2016). Revisiting Globalization Challenges and Opportunities in the Development of Cooperatives. Annals of Public and Cooperative Economics, 88(1), 47-73.

Cook, L. M. \& Chaddad R. F. (2004). Understanding New Cooperative Models: An Ownership-Control Rights Typology. Review of Agricultural Economics, 26(3), 348-60.

Dakurah, H., Goddard, E. \& Osuteye, N. (2005). Attitudes Towards and Satisfaction with Cooperatives in Alberta: A Survey Analysis [annual meeting]. American Agricultural Economics Association, University of Alberta.

Flecha, R. \& Ngai, P. (2014). The Challenge for Mondragon: Searching for the Cooperative Values in Times of Internationalization. Organization, 21(5), 666-82.

Fulton, E. M. (1999). Cooperatives and Member Commitment. The Finnish Journal Of Business Economics, (4), 418-37.

Fulton, E. M. \& Giannakas, K. (2001). Organizational Commitment in a Mixed Oligopoly: Agricultural Co-operatives and Investor-owned Firms. American Journal of Agricultural Economics, 83, 1258-65.

Fulton, E. M. \& Giannakas, K. (2007). Agency and Leadership in Cooperatives. In K. Karantininis \& J. Nilsson (eds.), Vertical markets and cooperative hierarchies (pp. 93-113). Springer Academic Publications.

Grashuis, J. (2018). An Exploratory Study of Ownership and Governance Interrelationships in Traditional and Hybrid Farmer Cooperatives. Managerial and Decision Economics, 39(6), 664-73.

Grashuis, J. \& Cook, M. (2018). An Examination of New Generation Cooperatives in the Upperr Midwest: Successes, Failures, and Limitations. Annals of Public and Cooperative Economics, 89(4), 623-44.

Iliopoulos, C. \& Theodorakopoulou, I. (2014). Mandatory Cooperatives and the Free Rider Problem: The Case of Santo Wines in Santorini, Greece. Annals of Public and Cooperative Economics, 85(4), 663-81.

Isimwe, M. A., Mbabazize, P. M. \& Shukla, J. (2016). Assessment on the Influence of Coffee Cooperatives Activities on Member's Welfare: A Case Study of Cocamu Cooperative, Rwanda. The International Journal of Business $\Theta^{\circ}$ Management, 4(4), 406-17.

Jensen, L. K. (1990). Factors Associated with the Selection of Cooperative vs. Proprietary Handlers of Milk in Tennessee. Journal of Agricultural Cooperation, 5, 27-35.

Kalogeras, N., Pennings, M.E., Van Dijk, G. \& Van Der Lans, A. (2007). The Structure of Marketing Cooperative: A Members' Perspective. In K. Karantininis \& J. Nilsson (eds.), Vertical markets and cooperative hierarchies (pp. 73-92). Springer Academic Publications.

Kokotas, N., Sergaki, P. \& Kalogeras, N. (2016, September 8-9). Measuring Members' Satisfaction from Agricultural Cooperatives [158th EAAE seminar]. Euro-Mediterranean Cooperation in Sustainable Agriculture and Food Security: Policies, Sustainability, Marketing and Trade, Mediterranean Agronomic Institute of Chania, Chania.

Kontogeorgos, A., Sergaki, P. \& Chatzitheodoridis, F. (2017). An Assessment of New Farmers' Perceptions about Agricultural Cooperatives. Journal of Development Enterpreneurship, 22(1).

Lampos, K. 1999. Cooperatives and Development. Athens, Greece.

Liebrand, B. C. \& Ling, K. C. (2014). Member Satisfaction with their Cooperatives: Insights from Dairy Farmers [research report 229]. USDA Rural Development, Rural Business Cooperative Center.

Liedtka, M. J. (1992). Exploring Ethical Issues Using Personal Interviews. Business Ethics Quarterly, 2, 161-81.

Morfi, C., Olilla, P., Nilsson, J., Feng, L. \& Karantininis, K. (2015). Motivation Behind Members ‘ Loyalty to Agricultural 
Cooperatives. In J. Windsperger, G. Cliquet, T. Ehrmann \& G. Hendrikse (eds.), Interfirm Networks (pp. 173-90). Springer, Cham.

Nishi, A. K. S. \& Kumar, R. (2011). Dairy Farmers' Satisfaction with Dairy Cooperative Societies: A Case Study. Indian Research Journal of Extension Education, 11(1).

Novkovic, S. (2008). Defining the Co-operative Difference. The Journal of Socio-Economics, 37, $2168-77$.

Österberg, P. \& Nilsson J. (2009). Members' Perception of their Participation in the Governance of Cooperatives: The Key to Trust and Commitment in Agricultural Cooperatives. Agribusiness. An International Journal, 25(2), 181-97.

Sergaki, P., Kontogeorgos, A., Kalogeras, N. \& Van Dijk, G. (2020). Reciprocity and Cooperative Performance: The Example of Mandatory Greek Cooperatives. Ager, 1(29), 7-38.

Staatz, M. J. (1987). The Structural Characteristics of Farmer Cooperatives and their Behavioral Consequences. In J.S. Royer (ed.), Cooperative Theory: New Approaches (pp. 33-60). U.S. Department of Agriculture, ACS Service Rep.

Tilahun, D. (2007). Performance of Coffee Marketing Co-operatives and Members; Satisfaction in Dale District: SNNPRSSouthern Ethiopia [M.Sc. Thesis, Haramaya University].

Trechter, D., King, P. R. \& Walsh, L. (2002). Using Communications to Influence Member Commitment in Cooperatives. Journal of Cooperatives, 17, 1-19.

Trinczek, R. (2009). How to Interview Managers? Methodical and Methodological Aspects of Expert Interviews as a Qualitative Method in Empirical Social Research. In Bogner A., Littig B. \& Menz W. (eds.), Interviewing Experts. Research Methods Series. Palgrave Macmillan.

Van Dijk, G. 1999. Evolution of Business Structure and Entrepreneurship of Cooperatives in the Horti- and Agribusiness. The Finish Journal of Business Economics, 4, 471-83.

Van Dijk, G., Sergaki, P. \& Baourakis, G. (2019). The Cooperative Enterprise: Practical Evidence for a Theory of Cooperative Entrepreneurship. Cham

Verhees, J.H.M. F., Sergaki, P. \& Van Dijk, G. (2015). Building up Active Membership in Cooperatives. New Medit, 14(1), 42-52. 